\title{
Real-world experience with tramadol plus dexketoprofen fixed-dose combination in postoperative pain management: A series of case studies from Asia
}

\author{
Kok Yuen Ho ${ }^{1 *}$, Edward H Wang ${ }^{2}$, Jose Antonio Salud ${ }^{3}$, Chi Wai Cheung ${ }^{4}$, Ferdinand Syfu ${ }^{5}$ and Keen Wai Chong ${ }^{6}$ \\ ${ }^{1}$ The Pain Clinic, Mt Alvernia Hospital, Singapore \\ ${ }^{2}$ Department of Orthopaedics, Philippine General Hospital, University of the Philippines Manila, Manila, Philippines \\ ${ }^{3}$ Department of Surgery, University of the East Ramon Magsaysay Memorial Medical Center (UERMMMC) College of Medicine, Quezon, Philippines \\ ${ }^{4}$ Department of Anaesthesiology, The University of Hong Kong, Hong Kong \\ ${ }^{5}$ Gen. Surgery Department, Delos Santos Sti Mega Clinic, Mandaluyong, Philippines \\ ${ }^{6}$ Department of Orthopaedic Surgery, BJIOS Orthopaedics, Singapore
}

\begin{abstract}
Background: Early and effective treatment of postoperative pain is vital for minimizing pain severity and optimizing patient outcomes and satisfaction. The efficacy and tolerability data of tramadol $75 \mathrm{mg}$ plus dexketoprofen $25 \mathrm{mg}$ fixed-dose combination (TRAM/DKP FDC) are reported in clinical trials but the data on realworld experience in postoperative pain management in the Asian population is limited.
\end{abstract}

Objectives: This series of case studies reviews clinicians' experience and outcomes of postoperative pain management in Asian patients using a TRAM/DKP FDC in the real-world setting.

Methods: Clinicians compiled, shared and discussed case studies of their experience using a TRAM/DKP FDC during two case studies expert meetings. A total of 13 case studies were shared across orthopaedic, soft tissue and laparoscopic surgery.

Results: All cases reported well-tolerated postoperative pain management with good pain relief with TRAM/DKP FDC.

Conclusions: TRAM/DKP FDC is an effective and well-tolerated option for the management of acute moderate-to-severe postoperative pain in Asian patients.

\begin{abstract}
Abbreviations: TRAM/DKP FDC: Tramadol $75 \mathrm{mg}$ plus dexketoprofen $25 \mathrm{mg}$ fixed-dose combination.

\section{Introduction}

Early and effective treatment of postoperative pain is vital for minimizing pain severity, and optimizing patient outcomes [1,2]. When postoperative pain is adequately managed, patients have a reduced risk of complications, improved physical functioning, shortened hospital stays, reduced opioid consumption, better quality of life outcomes and a reduced risk of chronic postsurgical pain (CPSP) [2-5]. Postoperative pain management should be started early, with prompt regimen adjustments as needed, to facilitate timely recovery [1].
\end{abstract}

Multimodal analgesia is the cornerstone of successful postoperative pain management, as recommended by the American Pain Society (APS) and the Australian and New Zealand College of Anaesthetists (ANZCA) [3,6]. Multimodal analgesia involves combining different modalities of analgesia to obtain synergistic effects, and thus more effective pain relief compared with single-modality interventions $[1,3,5]$. Combining medications that act via different mechanisms, or at different sites (e.g. peripherally vs centrally), can potentially provide a broader spectrum of pain relief and a complementary pharmacokinetic profile, while minimizing side effects associated with higher doses of single, equianalgesic interventions [7]. Multimodal analgesia has been shown to lower overall postoperative opioid consumption [8]. Oral, fixed-dose combinations are easy to administer, reducing pill burden and potentially increasing patient adherence to the pain protocol [9].

The APS and ANZCA postoperative pain management guidelines are endorsed in the Asia Pacific region by Malaysian, Hong Kong and Singapore pain associations and societies. The guidelines support the use of non-steroidal anti-inflammatory drugs (NSAID) as part of a multimodal regimen in postoperative patients $[3,6]$.

The fixed-dose combination of the long-acting opioid tramadol hydrochloride $75 \mathrm{mg}$ and the fast-acting NSAID dexketoprofen trometamol $25 \mathrm{mg}$ (TRAM/DKP FDC) is available to provide multimodal analgesia at lower and better tolerated doses than those of the single agents used alone [10]. A 2019 expert consensus DELPHI study on the use of orally-administered TRAM/DKP FDC for moderate-

${ }^{\star}$ Correspondence to: Kok Yuen Ho, The Pain Clinic, Mt Alvernia Hospital, 820 Thomson Rd, Singapore, Tel: +65 6254 5447; Fax: +65 6254 5477; Email: drho@ thepainclinic.com.sg

Key words: Dexketoprofen, multimodal analgesia, postoperative pain, tramadol

Received: November 21, 2020; Accepted: November 27, 2020; Published: December 04, 2020 
to-severe acute pain agreed that it had shown an analgesic efficacy greater than that achieved by either component in monotherapy for dental pain, soft tissue surgery and joint replacement surgery $[9,10]$.

While strong efficacy and tolerability data for a TRAM/DKP FDC are reported in clinical trials, there are a lack of data on real-world experience with this multimodal analgesic approach in postoperative pain management in the Asian population. This report describes 13 case studies to review its efficacy and tolerability in Asian patients.

\section{Methodology}

With a goal to optimize postoperative pain management across the Asia Pacific region, surgeons, anaesthesiologists and pain specialists compiled, shared, and discussed a series of case studies showcasing their experience using TRAM/DKP FDC in Asian patients from Singapore, Hong Kong and the Philippines. The cases were shared and discussed at two standalone case expert meetings held in 2019 and 2020.
Patients selected for the case studies had been pre-assessed for possible contraindications to the TRAM/DKP FDC, including renal impairment and history of gastrointestinal issues, prior to their selection. The real-world case study approach was intended to showcase the efficacy and safety of TRAM/DKP FDC in Asian patients across a variety of postoperative settings and provide treating clinicians with confidence to evaluate the clinical value of the TRAM/DKP FDC in suitable Asian patients.

\section{Results}

A real-world case study approach was used to examine the use of TRAM/DKP FDC in clinical practice in Asian patients. A total of 13 case studies are summarized below, with specific detail provided in Tables 1 and 2. The case studies are grouped by surgery type: Orthopaedic surgery, soft tissue surgery and other surgery.

Table 1. Case study details for the use of TRAM/DKP FDC in Asian Patients

\begin{tabular}{|c|c|c|c|c|}
\hline Case & Procedure & Case presentation & Postoperative pain management & Clinical course \\
\hline \multicolumn{5}{|c|}{ Orthopaedic surgery } \\
\hline 1 & $\begin{array}{l}\text { Hand fracture surgery \& } \\
\text { dental root canal }\end{array}$ & $\begin{array}{l}\text { 55/M businessman, weekend athlete, } \\
\text { injured his left-hand long finger at } \\
\text { basketball. Diagnosis: Fracture base of } \\
\text { middle phalanx, long finger. Surgical } \\
\text { plan: Closed reduction \& application } \\
\text { of dynamic external fixator, out-patient } \\
\text { procedure. }\end{array}$ & $\begin{array}{l}\text { Day 0-1: once awake from GA TRAM/DKP } \\
\text { FDC t.i.d. Day 2: TRAM/DKP FDC b.i.d. Day } 3 \\
\text { onwards: TRAM/DKP FDC t.i.d. }\end{array}$ & $\begin{array}{l}\text { On Day } 1 \text {, pain score dropped from } 9 / 10 \text { to } 1-2 / 10 \text {, } \\
\text { allowing immediate ROM for affected finger. } \\
\text { Shifted from t.i.d. to b.i.d. Day } 2 \text { because patient } \\
\text { felt sleepy. Day } 3 \text { resumed t.i.d. taken just before } \\
\text { performing exercises. Day } 4 \text { underwent a root } \\
\text { canal and did not require further analgesia. }\end{array}$ \\
\hline 2 & Total knee replacement & $\begin{array}{l}67 / \text { F experiencing osteoarthritis of the } \\
\text { knee for } 6 \text { years. No pain at rest; pain } \\
\text { on ambulation NRS } 6 / 10 \text {. Diagnosis: } \\
\text { osteoarthritis of the right knee. Surgical } \\
\text { plan: total knee replacement. }\end{array}$ & $\begin{array}{l}\text { Day 0: pre-op femoral nerve block; spinal } \\
\text { anaesthesia; IV cefazolin } 1 \mathrm{~g} \text {; IV dexamethasone } \\
8 \mathrm{mg} \text {, palonosetron } 75 \mathrm{mcg} \text {. At end of surgery: IV } \\
\text { parecoxib } 40 \mathrm{mg} \text {; IV paracetamol } 1 \mathrm{~g} \text {. Day 1: IV PCA } \\
\text { oxycodone (dilution } 1 \mathrm{mg} / \mathrm{ml}) \text {, bolus } 1 \mathrm{mg} \text {, lockout } 5 \\
\text { min, limit } 6 \mathrm{mg} / \text { hour; celecoxib } 200 \mathrm{mg} \text { b.i.d. Day 2: } \\
\text { IV PCA celecoxib. Day 3-8: TRAM/DKP FDC t.i.d. }\end{array}$ & $\begin{array}{l}\text { Discharged on Day 4. TRAM/DKP FDC t.i.d. well } \\
\text { tolerated. } \\
\text { No side effects were observed. }\end{array}$ \\
\hline 3 & Total knee replacement & $\begin{array}{l}\text { 65/M Diagnosis: osteoarthritis of } \\
\text { the knee. Surgical plan: total knee } \\
\text { replacement under spinal anaesthesia. }\end{array}$ & $\begin{array}{l}\text { Pregabalin } 75 \text { mg given the night before surgery } \\
\text { and } 2 \text { hours before surgery. Day 0: Intra-operative: } \\
\text { dexamethasone, morphine; intra-articular injection } \\
\text { with steroid, LA and ketorolac by surgeon. } \\
\text { Post-operative: paracetamol, TRAM/DKP FDC, } \\
\text { pregabalin at night. Temgesic PRN as first rescue } \\
\text { and Oxynorm PRN as second rescue. Day 1-5: } \\
\text { paracetamol; TRAM/DKP FDC; pregabalin at night. } \\
\text { Temgesic PRN as first rescue and Oxynorm PRN as } \\
\text { second rescue. Day } 5 \text { onwards: TRAM/DKP FDC } \\
\text { PRN. Pantoprazole } 40 \mathrm{mg} \text { IV given daily for } 2 \text { days } \\
\text { from post-operative day } 0 .\end{array}$ & $\begin{array}{l}\text { Pain control was good, and patient could walk Day } \\
\text { 1. Stable and discharged at Day } 5 \text {. } \\
\text { Throughout, pain scores (NRS) were less than } 3 \\
\text { or minimal during rest. NRS pain scores were less } \\
\text { than } 4 \text { during walking. } \\
\text { No side effects were observed. }\end{array}$ \\
\hline 4 & $\begin{array}{l}\text { Tumour excision and total } \\
\text { knee replacement }\end{array}$ & $\begin{array}{l}\text { 61/F presented with increasing difficulty } \\
\text { of knee in motion. } 10 \text {-year history } \\
\text { of left-knee fullness. Biopsy } 5 \text { years } \\
\text { ago suggested possible chondroma; } \\
\text { no further treatment given at that } \\
\text { time. X-ray revealed left knee lesions, } \\
\text { possibly chondroid in nature: synovial } \\
\text { chondromatosis. Diagnosis: benign } \\
\text { joint tumour (possibly synovial } \\
\text { chondromatosis or pigmented } \\
\text { villondular synovitis). Surgical plan: } \\
\text { total knee replacement (TKR) using } \\
\text { fully constrained TKR prosthesis: the } \\
\text { osteotomies required for TKR allowed } \\
\text { access to remove extensive lesions to } \\
\text { help prevent tumor recurrence. }\end{array}$ & $\begin{array}{l}\text { Day 0-1: drain within knee, knee immobilized. } \\
\text { Epidural morphine and paracetamol. Day 2: epidural } \\
\text { catheter removed. ROM exercises commenced. } \\
\text { TRAM/DKP FDC t.i.d. Day 3-6: TRAM/DKP FDC } \\
\text { t.i.d. }\end{array}$ & $\begin{array}{l}\text { Extreme pain on epidural removal resolved to } \\
\text { moderate pain }(6 / 10) \text {. } \\
\text { Pain control allowed for early range of motion } \\
\text { exercises. } \\
\text { Discharged Day } 3 \text {. Walker ambulation Day } 4 \text { with } \\
\text { only mild pain }(3 / 10) \text {. } \\
\text { No side effects were observed. }\end{array}$ \\
\hline
\end{tabular}




\begin{tabular}{|c|c|c|c|c|}
\hline 5 & $\begin{array}{l}\text { Orthopaedic hip } \\
\text { replacement }\end{array}$ & $\begin{array}{l}\text { 64/F, relatively healthy, but avoids } \\
\text { doctors. } \\
\text { Fell at home (slipped on loose carpet); } \\
\text { severe pain on ambulation. X-ray } \\
\text { one day later. Patient initially refused } \\
\text { treatment; but because of severe pain on } \\
\text { ambulation, she agreed to be admitted. } \\
\text { Diagnosis: Displaced right hip fracture } \\
\text { (femoral neck). Surgical plan: total } \\
\text { hip replacement in lateral position with } \\
\text { anterior approach. }\end{array}$ & $\begin{array}{l}\text { Day 0-1: epidural morphine and paracetamol. Day } \\
\text { 2: epidural catheter removed. TRAM/DKP FDC ti.i.d. } \\
\text { Day } 3 \text { onwards: TRAM/DKP FDC t.i.d. }\end{array}$ & $\begin{array}{l}\text { Partial weight-bearing walker-assisted ambulation, } \\
\text { with precautions against dislocation on Day } 1 \text {. By } \\
\text { Day } 2 \text { patient continues walker ambulation and is } \\
\text { less hesitant to mobilize. } \\
\text { Extreme pain }(8 / 10) \text { on epidural removal resolved } \\
\text { to moderate pain }(5 / 10) \text {. Onset of pain control was } \\
\text { fast and sustained. } \\
\text { TRAM/DKP FDC regimen facilitated early } \\
\text { mobilization. } \\
\text { Patient discharged Day 3. At 1-week follow-up } \\
\text { patient has ongoing therapy, walking comfortably, } \\
\text { no pain, mild soreness over hip. } \\
\text { No side effects were observed. }\end{array}$ \\
\hline 6 & Midfoot arthrodesis & $\begin{array}{l}\text { 56/M, Caucasian, } 80 \mathrm{~kg} \text {. Diagnosis: } \\
\text { midfoot osteoarthritis. Surgical plan: } \\
\text { midfoot arthrodesis, with popliteal } \\
\text { saphenous nerve block under general } \\
\text { anaesthesia. }\end{array}$ & $\begin{array}{l}\text { Day 0-2: paracetamol } 1 \mathrm{~g}, 6 \text { hourly; TRAM/DKP } \\
\text { FDC ti.i.d. Day 3-4: TRAM/DKP FDC t.i.d. Day 5: } \\
\text { etoricoxib 90mg om for } 1 \text { week }\end{array}$ & $\begin{array}{l}\text { Pain control was good; VAS }<4 \text { in general. } \\
\text { Patient went home on Day } 3 \text {. } \\
\text { No side effects were observed. }\end{array}$ \\
\hline \multicolumn{5}{|c|}{ Soft tissue surgery } \\
\hline 7 & Haemorrhoidectomy & $\begin{array}{l}55 / \mathrm{M} \text { with bleeding anal mass. History } \\
\text { of chronic constipation and prolonged } \\
\text { sitting in bathroom and straining. } \\
\text { Diagnosis: internal haemorrhoids, Grade } \\
\text { 3. Surgical plan: haemorrhoidectomy } \\
\text { under general anaesthesia }\end{array}$ & $\begin{array}{l}\text { Day 0: warm sitz bath; } 2 \text { x IV dexketoprofen } 50 \\
\text { mg; stool softeners. Day 1: TRAM/DKP FDC } \\
\text { b.i.d. Day 2-3: TRAM/DKP FDC b.i.d. Day 4-6: } \\
\text { dexketoprofen } 25 \mathrm{mg}\end{array}$ & $\begin{array}{l}\text { Onset of action within } 20 \text { minutes for first dose of } \\
\text { TRAM/DKP FDC. Onset of action even shorter } \\
\text { subsequently. Light headedness on day } 1 \text { that } \\
\text { resolved within a few hours and was absent on } \\
\text { subsequent dosing } \\
\text { Patient discharged day } 1 \text { with adequate pain relief. } \\
\text { Day } 3 \text { follow-up: pain control is satisfactory - } \\
\text { step-down medication to NSAID only. }\end{array}$ \\
\hline 8 & Haemorrhoidectomy & $\begin{array}{l}\text { 39/M with 3-year history of palpable } \\
\text { anal mass with occasional scanty } \\
\text { bleeding. Noted } 1 \text { day prior to have } \\
\text { severe anal pain }(10 / 10) \text { with enlarged } \\
\text { anal mass. Work up showed } 3 \times 5 \mathrm{~cm} \\
\text { thrombosed haemorrhoid on the } \\
\text { left lateral. Diagnosis: thrombosed } \\
\text { haemorrhoid. Surgical plan: } \\
\text { haemorrhoidectomy }\end{array}$ & $\begin{array}{l}\text { Day 0: Intra-operative - dexketoprofen IV, } 1 \text { dose; } \\
\text { post-operative - dexketoprofen IV } 2 \text { doses; TRAM/ } \\
\text { DKP FDC. Day 1-2: TRAM/DKP FDC t.i.d. }\end{array}$ & $\begin{array}{l}\text { Post-op pain control was good; VAS decreased to } \\
<3 \text { from } 10 \text {. } \\
\text { Minimal drowsiness; no nausea or vomiting. }\end{array}$ \\
\hline 9 & Haemorrhoidectomy & $\begin{array}{l}\text { 35/M presents with painful } \\
\text { prolapsed piles. Surgical plan: } \\
\text { haemorrhoidectomy under day surgery. }\end{array}$ & $\begin{array}{l}\text { Day 0: IV fentanyl } 75 \mathrm{mcg} \text {; propofol } 120 \mathrm{mg} \text {; } \\
\text { LMA } \# 4 \text {; GA - Sevoflurane in air/oxygen; IV } \\
\text { dexamethasone } 8 \mathrm{mg} \text {; IV ondansetron } 4 \mathrm{mg} \text {; IV } \\
\text { oxycodone } 5 \mathrm{mg} \text {; IV parecoxib } 40 \mathrm{mg} \text {. Day 1: } \\
\text { Lactulose } 20 \mathrm{ml} \text { ON; Daflon } 2 \text { tab b.i.d.; topical } \\
\text { lignocaine } 2 \% \text { gel; TRAM/DKP FDC t.i.d. for } 5 \text { days. }\end{array}$ & $\begin{array}{l}\text { Discharged same day. } \\
\text { No side effects were observed. }\end{array}$ \\
\hline 10 & Mastectomy & $\begin{array}{l}\text { 55/F with mass on right breast reported } \\
\text { as } 1 \mathrm{~cm} 2 \text { years prior to admission. } 3 \\
\text { months prior to admission mass was } \\
2 \mathrm{~cm} \text { and mammography and ultrasound } \\
\text { performed. 1-month prior core 4needle } \\
\text { biopsy ordered. Diagnosis: invasive } \\
\text { ductal carcinoma Stage 2A. Surgical } \\
\text { plan: modified radical right mastectomy. }\end{array}$ & $\begin{array}{l}\text { Day 0: diet started once patient was awake; } 2 \text { x IV } \\
\text { dexketoprofen } 50 \mathrm{mg} \text {; oral dexketoprofen trometamol } \\
\text { t.i.d. Day 1: TRAM/DKP FDC t.i.d. Day 2-4: } \\
\text { TRAM/DKP FDC t.i.d. Day 3-6: oral dexketoprofen } \\
25 \text { mg t.i.d. }\end{array}$ & $\begin{array}{l}\text { Pain rated } 4 / 10 \text { after surgery; but resolved to } \\
1 / 1015-20 \text { minutes after intake of first tablet. No } \\
\text { nausea and vomiting reported. } \\
\text { Initial light headedness for a few hours then } \\
\text { subsided. Recurred after the next few doses, } \\
\text { Discharged Day 1. }\end{array}$ \\
\hline 11 & $\begin{array}{l}\text { Open cholecystectomy, } \\
\text { intraoperative } \\
\text { cholangiogram, common } \\
\text { bile duct exploration }\end{array}$ & $\begin{array}{l}\text { 43/M with 2-year history of intermittent } \\
\text { RUQ pain. Patient self-medicated with } \\
\text { OTC meds which provided relief. } 1 \\
\text { week prior to admission, the patient } \\
\text { noted recurrence of RUQ pain, now } \\
\text { more severe. Persistent icteric sclerae, } \\
\text { jaundice and episodes of tea-coloured } \\
\text { urine. Work up noted cholelithiasis } \\
\text { and choledocholithiasis. Diagnosis: } \\
\text { Obstructive jaundice secondary to } \\
\text { choledocholithiasis with acute calculous } \\
\text { cholecystitis. Surgical plan: ERCP with } \\
\text { attempted stone extraction. }\end{array}$ & $\begin{array}{l}\text { Day 0: Intra-operative - dexketoprofen IV, } 1 \text { dose; } \\
\text { post-operative - dexketoprofen IV } 2 \text { doses; TRAM/ } \\
\text { DKP FDC; paracetamol } 500 \text { mg IV every } 6 \text { hours for } \\
\text { breakthrough pain. Day 1-4: TRAM/DKP FDC t.i.d. }\end{array}$ & $\begin{array}{l}\text { Post-op pain control was good; VAS decreases } \\
\text { to }<5 \text { from } 9 / 10 \text {. Able to ambulate early despite } \\
\text { expected pain from nature of surgery. } \\
1 \text { episode of drowsiness without recurrence. }\end{array}$ \\
\hline \multicolumn{5}{|c|}{ Other surgery } \\
\hline 12 & $\begin{array}{l}\text { Video-assisted } \\
\text { thoracoscopic surgery } \\
\text { (lung resection) }\end{array}$ & $\begin{array}{l}\text { 60/M with a } 40 \text {-year history of smoking. } \\
\text { Diagnosis: lung cancer. Surgical plan: } \\
\text { video-assisted thoracoscopic lung } \\
\text { resection. }\end{array}$ & $\begin{array}{l}\text { Pregabalin } 75 \mathrm{mg} \text { given the night before surgery } \\
\text { and } 2 \text { hours before surgery. Day 0: Intra-operative: } \\
\text { paravertebral block, ketamine, morphine. Post- } \\
\text { operative: paracetamol; TRAM/DKP FDC, } \\
\text { pregabalin; Oxynorm and temgesic on request. Day } \\
\text { 1-2: paracetamol; TRAM/DKP FDC; pregabalin. } \\
\text { Oxynorm and temgesic on request. Day } 3 \text { onwards: } \\
\text { TRAM/DKP FDC on request. Pregabalin continued } \\
\text { for } 2 \text { more days. }\end{array}$ & $\begin{array}{l}\text { Post-operative pain control was good with } \\
\text { consistent NRS less than } 3 / 10 \text {. } \\
\text { Patient had mild nausea at Day 0, which was } \\
\text { managed well with PRN Zofran. }\end{array}$ \\
\hline
\end{tabular}




\begin{tabular}{|l|l|l|l|}
\hline 13 & $\begin{array}{l}\text { 25/M with a 5-year history of abdominal } \\
\text { pain, initially epigastric later radiating } \\
\text { to right lower quadrant. Presents with } \\
\text { fever, nausea and vomiting. Diagnosis: } \\
\text { acute appendicitis, possibly ruptured. } \\
\text { Surgical plan: emergency midline } \\
\text { laparotomy under general anaesthesia. } \\
\text { Preoperative antibiotics given. }\end{array}$ & $\begin{array}{l}\text { Laparotomy } \\
\text { Day 0: Nil by mouth; parenteral medication Day 1: } \\
\text { progressive diet begun in the afternoon; parenteral } \\
\text { medication Day 2: parenteral medication. Day 3-6: } \\
\text { TRAM/DKP FDC b.i.d. Day 6-8: oral dexketoprofen } \\
\text { 25 mg t.i.d. } \\
\text { dexketoprofen 25 mg, which resolved within an } \\
\text { hain control remarkably achieved with TRAM/ } \\
\text { DKDC. } \\
\text { At follow up on Day 7, the patient was well with } \\
\text { no side effects observed. }\end{array}$ \\
\hline
\end{tabular}

AE: Adverse event; BID: Two times a day; COX1: Cyclooxygenase 1; COX2: Cyclooxygenase 2; ERCP: Endoscopic retrograde cholangio- pancreatography; MRCP: Magnetic resonance cholangiopancreatography; PCA: Patient-controlled analgesia; PONV: Postoperative nausea and vomiting; PRN: Pro Re Nata; if necessary; ROM: Range of movement; RUQ: Right upper quadrant; TID: Three times a day; VAS: Visual analogue scale

Table 2. Safety and tolerability outcomes reported in the case studies

\begin{tabular}{|c|c|c|}
\hline Case & Procedure & Adverse events or reactions \\
\hline 1 & $\begin{array}{c}\text { Hand fracture surgery \& dental root } \\
\text { canal }\end{array}$ & No AEs were observed \\
\hline 2 & Total knee replacement & No AEs were observed \\
\hline 3 & Total knee replacement & No AEs were observed \\
\hline 4 & $\begin{array}{c}\text { Tumor excision and total knee } \\
\text { replacement }\end{array}$ & No AEs were observed \\
\hline 5 & Orthopedic hip replacement & No AEs were observed \\
\hline 6 & Midfoot arthrodesis & No AEs were observed \\
\hline 7 & Hemorrhoidectomy & Light-headedness Day 1 \\
\hline 8 & Hemorrhoidectomy & Minimal drowsiness \\
\hline 9 & Hemorrhoidectomy & No AEs were observed \\
\hline 10 & Mastectomy & Light-headedness Day 1 \\
\hline 11 & $\begin{array}{c}\text { Open cholecystectomy, intraoperative } \\
\text { cholangiogram, common bile duct } \\
\text { exploration }\end{array}$ & Drowsiness without recurrence \\
\hline 12 & $\begin{array}{c}\text { Video-assisted thoracoscopic surgery } \\
\text { (lung resection) }\end{array}$ & Mild nausea Day 0 \\
\hline 13 & Laparotomy & Dizziness Day 1 \\
\hline
\end{tabular}

\section{Orthopaedic surgery}

\section{Case 1}

Case 1 describes the unique postoperative pain management of a 55y male who underwent surgery for a fractured hand, followed by root canal on postoperative day 4 . In this case, the TRAM/DKP FDC was initiated on the day of surgery and administered three times a day for the first 48 hours. On postoperative day 4 , the patient underwent root canal surgery and did not require any pain relief in addition to the TRAM/DKP FDC.

\section{Case 2}

Case 2 describes the postoperative pain management of a $67 y$ female undergoing total knee replacement. The TRAM/DKP FDC was initiated three-times daily from postoperative day 3, following a combination of IV opioid and NSAID patient-controlled analgesia (PCA) from the day of surgery through to postoperative day 2.

\section{Case 3}

Case 3 describes the postoperative pain management of a $65 \mathrm{y}$ male undergoing total knee replacement. The TRAM/DKP FDC was initiated on the day of surgery in addition to paracetamol. From postoperative day 5 onward, the TRAM/DKP FDC was administered when required.

\section{Case 4}

Case 4 describes the postoperative pain management of a $61 \mathrm{y}$ female undergoing total knee replacement following excision of an extensive pigmented villonodular synovitis (PVNS). The TRAM/DKP FDC was initiated on postoperative day 2 following discontinuation of epidural morphine.

\section{Case 5}

Case 5 describes the postoperative pain management of a $64 y$ female undergoing an orthopaedic hip replacement. Following a regimen of epidural morphine and paracetamol for the initial 48 hours post operation, TRAM/DKP FDC was initiated on postoperative day 2.

\section{Case 6}

Case 6 describes the postoperative pain management of a 56y male undergoing midfoot arthrodesis for osteoarthritis. The patient had a popliteal saphenous nerve block given under general anaesthesia. The analgesic effect of this continued for up to 15-hours after surgery. A three-times-daily regimen of TRAM/DKP FDC was initiated on the day of surgery in addition to paracetamol $1 \mathrm{~g}$ every 6 hours. From postoperative day 5 , the patient was changed to a once-daily dose of etoricoxib 90mg, for 1 week.

\section{Soft tissue surgery}

\section{Case 7}

Case 7 describes the postoperative pain management of a $55 y$ male undergoing haemorrhoidectomy. Following management with IV dexketoprofen trometamol $50 \mathrm{mg}$ on the day of surgery, the patient was transitioned to a twice-daily dose of TRAM/DKP FDC on postoperative day 1.

\section{Case 8}

Case 8 describes the postoperative pain management of a 39y male undergoing haemorrhoidectomy. Following administration of intraoperative IV dexketoprofen and oral dexketoprofen in the immediate postoperative period, the TRAM/DKP FDC was initiated on the day of surgery. A three-times-daily regimen was maintained for postoperative day 1 and 2 .

\section{Case 9}

Case 9 describes the postoperative pain management of a $35 y$ male undergoing haemorrhoidectomy. Following management with a combination of IV opioids and NSAIDs on the day of surgery, the patient was discharged on a regimen of three-times-daily TRAM/DKP FDC for five days, in addition to adjuvant laxative, a topical numbing agent and Daflon.

\section{Case 10}

Case 10 describes the postoperative pain management of a $55 y$ female undergoing a modified radical unilateral mastectomy. Following management with a combination of IV and oral dexketoprofen trometamol on the day of surgery, the patient was transitioned to TRAM/DKP FDC on postoperative day 1.

\section{Case 11}

Case 11 describes the postoperative pain management of a $43 y$ male undergoing an open cholecystectomy, with intraoperative 
cholangiogram and common bile duct exploration, following a diagnosis of obstructive jaundice secondary to choledocholithiasis with acute calculous cholecystitis. Following intraoperative dexketoprofen IV, TRAM/DKP FDC was initiated on the day of surgery in addition to paracetamol $500 \mathrm{mg}$ IV every six hours for breakthrough pain. From postoperative day 1 to day 4 , postoperative pain was managed with a three-times-daily regimen of TRAM/DKP FDC.

\section{Other surgery}

\section{Case 12}

Case 12 describes the postoperative pain management of a $60 \mathrm{y}$ male undergoing video-assisted lung resection. Following perioperative management with pregabalin $75 \mathrm{mg}$, TRAM/DKP FDC was initiated on the day of surgery in addition to paracetamol, with oxycodone and pregabalin when required. This regimen was continued until postoperative day 3, at which time the TRAM/DKP FDC and paracetamol were administered when required.

\section{Case 13}

Case 13 describes the postoperative pain management of a $25 y$ male undergoing an emergency midline laparotomy for an enlarged appendix. Following parenteral medication on the day of surgery and postoperative days 1 and 2, the patient was transitioned to TRAM/DKP FDC from day 3.

\section{Discussion}

\section{The rationale for a tramadol and dexketoprofen fixed-dose combination}

The TRAM/DKP FDC was first approved for use in Europe in 2016 and introduced across the Asia Pacific region from 2018. It is indicated for the short-term, symptomatic relief of moderate-to-severe acute pain [9]. In development, tramadol and dexketoprofen were considered an appropriate pairing in a fixed-dose combination due to their different modes and sites of action, their complementary pharmacokinetic profiles and their favourable safety profile compared with other NSAIDs or opioids [9].
Dexketoprofen is a traditional, non-selective NSAID inhibiting the cyclooxygenase pathway at both COX-1 and COX-2 [9]. It acts centrally and peripherally, reducing prostaglandins at the site of injury and also in the central nervous system to reduce pain response [11]. It has been shown to be as effective as other NSAIDs or paracetamol/ opioid combinations, with rapid onset of analgesic activity within 15 minutes $[9,12]$. In addition to the proven efficacy and rapid onset of action, dexketoprofen is generally well-tolerated with a favourable gastrointestinal and cardiovascular safety profile. It is associated with a lower risk of NSAID-induced gastrointestinal bleeding compared with several other commonly used NSAIDs, including meloxicam, ibuprofen, diclofenac and ketoprofen [13]. It has also been associated with a lower risk of heart failure compared with other NSAIDs in a population-based analysis of hospitalized patients in Europe $[9,14,15]$. In an analysis of NSAID use in patients admitted to hospital with heart failure, dexketoprofen had the second lowest risk of heart failure compared with other NSAIDs [14].

Tramadol is a centrally acting $\mu$-opioid receptor agonist and serotonin/norepinephrine reuptake-inhibitor (SNRI) that has been demonstrated to achieve comparable relief to equianalgesic doses of parenteral morphine or alfentanil $[9,15]$. It has a long duration of action and, unlike other opioids, has no clinically relevant effects on respiratory and cardiovascular parameters [15-18].

The long-lasting, central analgesia of tramadol and the fast-acting, central and peripheral analgesic and anti-inflammatory action of dexketoprofen combine synergistically in the TRAM/DKP FDC to deliver greater analgesic efficacy at lower dosages than the individual components with fewer adverse reactions [16-18] (Figure 1).

In acute pain, the typical dose of tramadol monotherapy is 50-100 mg three or four times a day. In the TRAM/DKP FDC, the dose of tramadol is $75 \mathrm{mg}$, three times a day. The lower dose results in a lower incidence of adverse effects. Improved analgesia with lower adverse effects may lead to shorter hospitalization times, improved recovery and function and possibly decreased healthcare costs $[19,20]$.

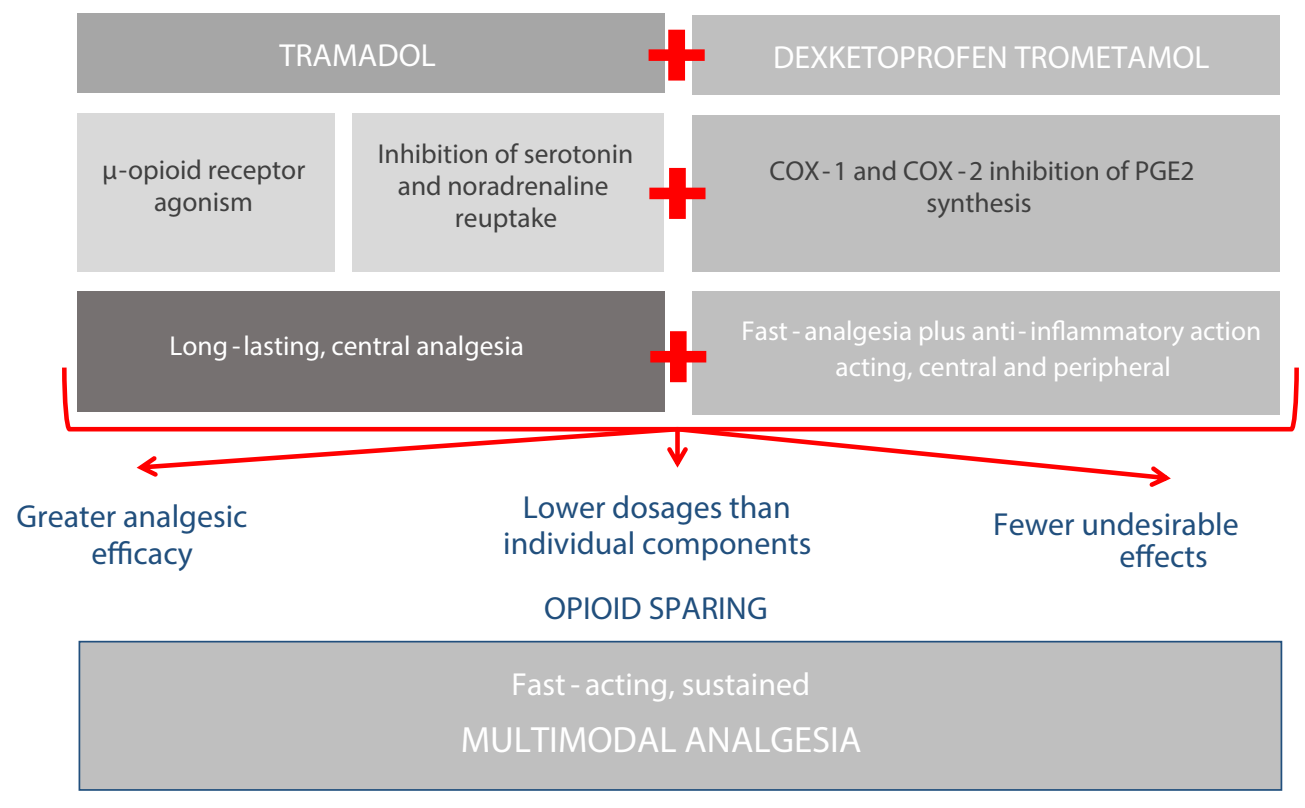

Figure 1. Multimodal analgesia with the TRAM/DKP FDC $[9,11,12,15-18]$ 


\section{Tramadol and dexketoprofen fixed-dose combination in clinical trials}

The efficacy, safety and tolerability of the TRAM/DKP FDC has been demonstrated in randomized trials involving 1853 patients [1618]. In addition, one post-hoc analysis and one head-to-head clinical trial have also been undertaken $[21,22]$.

In pivotal trials, the TRAM/DKP FDC demonstrated superior pain relief compared with placebo, and monotherapy tramadol $100 \mathrm{mg}$ and dexketoprofen $25 \mathrm{mg}$ [16-18]. The TRAM/DKP FDC was also proven to be superior to a paracetamol plus tramadol combination over 6 hours [16].

The TRAM/DKP FDC demonstrates fast and sustained analgesia. In the Phase II dose-finding trial, dexketoprofen alone, or in combination, demonstrated rapid onset of pain relief. The addition of tramadol to dexketoprofen resulted in a greater peak pain relief and greater relief over the long-term [16]. The post-hoc analysis of the Phase III and Phase IIIb trials determined that TRAM/DKP FDC provides superior analgesia for a longer duration, up to 56 hours, compared with tramadol $100 \mathrm{mg}$ or dexketoprofen $25 \mathrm{mg}$ alone [21].

The safety and tolerability of the TRAM/DKP FDC observed in the pivotal trials was demonstrated to be in line with that observed in previous clinical experience with tramadol and dexketoprofen monotherapy [16-18]. In these trials, common adverse reactions included vomiting, nausea and dizziness [16-18]. The TRAM/DKP FDC consistently reported a lower incidence of adverse drug reactions in comparison to the tramadol and dexketoprofen monotherapy [1618].

Tramadol and dexketoprofen fixed-dose combination in Asian patients

The 13 case studies reported here provide the first published data of the real-world efficacy and tolerability of TRAM/DKP FDC in Asian patients.

\section{Pain control in Asian patients}

Postoperative pain was adequately controlled with TRAM/DKP FDC in all reported case studies. In 8 of the 13 cases, TRAM/DKP FDC was the only analgesic required once initiated. In cases 1, 3, 4 and 5, TRAM/DKP FDC was credited with facilitating early mobilization.

All treating clinicians observed adequate postoperative pain management. In cases 3, 7 and 12 the treating clinicians noted the benefit of the multimodal combination in addressing nociceptive, neuropathic and inflammatory pain in one, convenient tablet.

The rapid onset of action of TRAM/DKP FDC was also viewed as advantageous. Onset of pain relief was reported as 'fast' in 3 case studies, with cases 7 and 10 specifying this relief occurred within 20 minutes. These findings in Asian patients are consistent with the known mechanism of action of TRAM/DKP FDC and with the outcomes of clinical trials. Dexketoprofen alone, or as part of the TRAM/DKP FDC demonstrates rapid onset of pain relief. In the Phase II dose-finding trial, the TRAM/DKP FDC resulted in the most rapid onset and the greatest peak pain relief [16-18].

\section{Safety and tolerability in Asian patients}

No serious side effects or adverse reactions were reported across all case studies. Cases 7, 9 and 13 noted some light-headedness/dizziness that resolved in each of these cases within a short period of time. This finding is consistent with the tolerability outcomes of clinical trials in which 'dizziness' is noted as a common, yet minor, adverse reaction [1618]. Minimal drowsiness was reported in cases 8 and 11. No patient discontinued the TRAM/DKP FDC during the prescribed treatment period.

\section{Satisfaction score on analgesia and tolerability of TRAM/ DKP FDC among Asian patients}

Satisfactory postoperative pain relief was reported in each case study. Treating clinicians reported high levels of satisfaction (measured as a score of 4 or 5 on a 5 -point scale) with the analgesia provided by the TRAM/DKP FDC and on its tolerability among patients.

\section{Limitations}

The limitations of this series of case studies relate primarily to its retrospective and case-selective design. All data were clinician reported and no standard scale was used across the cases for the assessment of postoperative pain. No direct survey of the patients presented in this case series was conducted. There was no uniformity in the use of preand intra-operative analgesics. In addition, some patients had additional postoperative pain relief while receiving the TRAM/DKP FDC.

\section{Conclusion}

This case series comprises the first published, real-world experience of TRAM/DKP FDC in Asian patients. Consistent with clinical trial outcomes, TRAM/DKP FDC provided adequate postoperative pain relief and was well-tolerated within the patient population. The high-level of satisfaction reported by both treating clinicians and patients indicates that TRAM/DKP FDC is an effective choice for postoperative pain management in Asian patients.

\section{Acknowledgment}

Case studies were provided by all authors $(\mathrm{KYH}, \mathrm{FS}, \mathrm{JAS}, \mathrm{CWC}$, $\mathrm{KWC}, \mathrm{EW}$ ) in the case sharing experts meeting held as standalone meeting in parallel to the Annual European Congress of Rheumatology 2019 and the 10th World Congress of the World Institute of Pain (WIP) 2020. KYH prepared the manuscript with the assistance of a medical writer who worked under his direction.

\section{Funding information}

The services of a medical writer were funded by Menarini Asia Pacific Pte Ltd.

\section{Competing interests}

The authors declare that the manuscript preparation was conducted in the absence of any commercial or financial relationships that could be construed as a potential conflict of interest. The authors were, however, paid honorarium to share their case studies for the case expert meetings in which the cases were presented and discussed.

\section{References}

1. Berry P (Ed) Pain: Current understanding of assessment, management and treatments Glenview IL, USA.

2. Garimella V, Cellini C (2013) Postoperative pain control. Clin Colon Rectal Surg 26: 191-196. [Crossref]

3. Roger C, Debra BG, Oscar A de Leon C, Jack MR, Stephen B (2016) Management of postoperative pain: A clinical practice guideline from the American pain society, the American Society of Regional Anesthesia and Pain Medicine, and the American Society of Anesthesiologists' Committee on Regional Anesthesia, Executive Committee, and Administrative Council. J Pain 17: 131-157. [Crossref] 
4. Gan TJ (2017) Poorly controlled postoperative pain: Prevalence, consequences, and prevention. J Pain Res 10: 2287-2298. [Crossref]

5. Kuusniemi K, Pöyhiä R (2016) Present-day challenges and future solutions in postoperative pain management: Results from pain forum 2014. J Pain Res 9: 25-36. [Crossref]

6. Stephan AS, Greta MP, David AS, Richard H, Jane T (2015) Acute pain management: Scientific evidence, fourth edition 2015. Med J Aust 204: 315-317. [Crossref]

7. Bhatia A, Buvanendran A (2019) Anesthesia and postoperative pain control multimodal anesthesia protocol. J Spine Surg 5: 160-165. [Crossref]

8. Magdolna B, Edit R, Dong Dong L, Li X, Lucy A, et al. (2019) A cost-consequence analysis of parecoxib and opioids vs opioids alone for postoperative pain: Chinese perspective. Clin Econ Outcomes Res 11: 169-177. [Crossref]

9. Giustino V, Magdi H, Giorgos M, Antonio M, Antonio M, et al. (2017) Multimoda analgesia in moderate-to-severe pain: A role for a new fixed combination of dexketoprofen and tramadol. Curr Med Res Opin 33: 1165-1173. [Crossref]

10. Giustino V, Stefano C, Josè De A, Magdi H, Giorgos M, et al. (2019) Expert consensus on clinical use of an orally administered dexketoprofen plus tramadol fixed-dose combination in moderate-to-severe acute pain: A delphi Study. Adv Ther 36: $3174-$ 3185. [Crossref]

11. Mauleón D, Artigas R, García ML, Carganico G (1996) Preclinical and clinical development of dexketoprofen. Drugs 52: 24-46. [Crossref]

12. Leman P, Kapadia Y, Herington J (2003) Randomised controlled trial of the onset of analgesic efficacy of dexketoprofen and diclofenac in lower limb injury. Emerg Med $J$ 20: 511-513. [Crossref]

13. Laporte J-R, Ibáñez L, Vidal X, Vendrell L, Leone R (2004) Upper gastrointestinal bleeding associated with the use of NSAIDs: Newer versus older agents. Drug saf 27: 411-420. [Crossref]
14. Arfè A, Scotti L, Varas-lorenzo C, Nicotra F, Federica N, Antonella Z et al. (2016) Nonsteroidal anti-inflammatory drugs and risk of heart failure in four European countries: Nested case-control study. BMJ Open 354: i4851. [Crossref]

15. Scott LJ, Perry CM (2000) Tramadol: A review of its use in perioperative pain. Drugs 60: 139-176. [Crossref]

16. Moore RA, Gay-Escoda C, Figueiredo R, Tóth-Bagi Z, Dietrich T, et al. (2015) Dexketoprofen/tramadol: Randomised double-blind trial and confirmation of empirical theory of combination analgesics in acute pain. J Headache Pain 16: 541. [Crossref]

17. Moore RA, McQuay HJ, Tomaszewski J, Raba G, Tutunaru D et al. (2016) Dexketoprofen/tramadol $25 \mathrm{mg} / 75 \mathrm{mg}$ : Randomised double-blind trial in moderate-tosevere acute pain after abdominal hysterectomy. BMC Anesthesiology 16.

18. McQuay HJ, Moore RA, Berta A, Gainutdinovs O, Fülesdi B, et al. (2016) Randomized clinical trial of dexketoprofen/tramadol $25 \mathrm{mg} / 75 \mathrm{mg}$ in moderate-to-severe pain after total hip arthroplasty. Br J Anaesth 116: 269-276. [Croosref]

19. Miranda HF, Puig MM, Romero MA, Prieto JC (2009) Effects of tramadol and dexketoprofen on analgesia and gastrointestinal transit in mice. Fundam Clin Pharmacol 23: 81-88. [Crossref]

20. Miranda HF, Prieto JC, Puig MM, Pinardi G (2008) Isobolographic analysis of multimodal analgesia in an animal model of visceral acute pain. Pharmacol Biochem Behav 88: 481-486. [Crossref]

21. Montero Matamala A, Bertolotti M, Contini MP, Guerrero Bayón C, Nizzardo A (2017) Tramadol hydrochloride $75 \mathrm{mg} /$ dexketoprofen $25 \mathrm{mg}$ oral fixed-dose combination in moderate-to-severe acute pain: Sustained analgesic effect over a 56-h period in the postoperative setting. Drugs Today 53: 339-347. [Crossref]

22. Cosme Gay E, Magdi H, Antonio M, Thomas D, Stefano M (2019) Tramadol dexketoprofen (TRAM/DKP) compared with tramadol/paracetamol in moderate to severe acute pain: Results of a randomised, double-blind, placebo and active-controlled, parallel group trial in the impacted third molar extraction pain model (DAVID study). BMJ Open 9: e023715. [Crossref]

Copyright: (C2020 Ho KY. This is an open-access article distributed under the terms of the Creative Commons Attribution License, which permits unrestricted use, distribution, and reproduction in any medium, provided the original author and source are credited. 